\title{
Actants of manipulative communication
}

\author{
Ştefan Vlăduţescu \\ University of Craiova, 13 A. I. Cuza Street, 200585, Craiova, Romania \\ E-mail address: stefan.vladutescu@yahoo.com
}

\begin{abstract}
The study starts from assumption that together with disinfomation, intoxica the manipulation is a form of persuasion, a form of persuasive communicatio. The manipu on $\mathrm{s}$ a communicative action. By the way of meta-analytical method, we emphasize ne ide The ro d way of promoting the decisive interests is manipulation-, often accompanie $y$ aints an violence. The world is divided into amateur manipulators and professional mani alators. A ssior als are those whose job is exactly to get something from the others. The actio a anipulation not an activity performed on inspiration, randomly and by ear. Manipulation i. stru ed, organ ised and planned persuasive intervention. As actants of manipulative commy ton are ned journalists, priests, businessmen, sellers, scholars, teachers, artists, writers, no abilities.

Keywords: communication; manipulative communication rots; actar s

\section{INTRODUCTION}

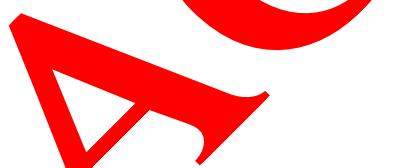

The action is performed a dy amic an Controlled process. The management of the action of manipulation is done de specialists working in teams.

The plan of the act on of ma plation, the basic document of organising and planning the persuasive interver 1 is structur 1 us:

- analysinoth socià ntext and actual situation;

- defini g the issues ra by the current situation;

- sett o the ls and establishing the manipulating objectives;

- delin the tar ts of the intervention (as elements of knowledge and as target

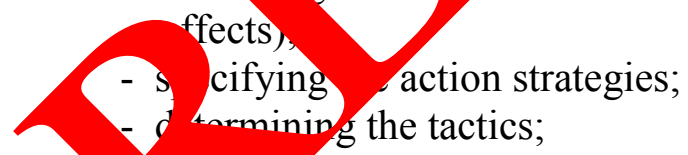

Tutlinm the anticipation device (feed-forward) and feed-back of the intervention;

- asing the methods, procedures and means to implement the strategies and tactics to achieve the objectives;

- setting the self-protective, informational and psychological coordinates of the manipulating message;

- setting the propagation channels;

- establishing the work schedule;

- forecasting the budget;

- determining the procedures of evaluation.
\end{abstract}


Our world is composed by amateur manipulators and professional manipulators. Professionals get ever something from the others (Borowski, 2013; Borowski, 2014). Professionals are sellers, chiefs, social workers, teachers, etc. The sellers are some manipulators. For example, they can sell soaps to us, either forcing us to try a sample, or insisting to inform us we need to stay young and with a soft skin: this is why we need the soap. In the first case, by manipulation, they "force" us to buy, imposing a preset behaviour to us. In the second case, they impose a status of idiots to us, meaning the status of someone who buys a product for some qualities which directly it does not truly have to a larger extent than competing products (Johnson, Hample, \& Cionea, 2014). In the first situation, they sell soap to us without offering us the reasons why to choose that type, and in the second sicuation, $y$ sell a soap to use, offering false motives.

\section{TARGETS AND ACTANTS OF MANIPULATIVE COMMU CATI}

The targets of manipulation are human subjects as indiy ual, grou cor coctiveness which are subject to manipulating influence. In relation to the $\mathrm{y}_{\mathrm{p}}$ manipul $\mathrm{c}$, the sources of manipulation can be: individuals, groups or collectiver ss. he case of interpersonal manipulation, the actors are individuals in their capaci y as a privato vidual. But when it comes to the manipulations of collectiveness, then th source becomes omplex.

The source-actants are the latent partners and $t$ specialists. The latent partners are those individuals or groups interested in manipulating cert collectiv ies. The latent partners may be governments, military general staffs, inte 11 igence sè ocio-professional organisations or groups of interests or of pressure (busin trade unions, etc.). Ultimately, the latent partners are decision-makers. They turn to son e sr com is who deal with designing, planning, organising and implementing the manipulating itervention.

The actants of manipulation hemsel s, those whom translate the plans into manipulation, those who com and slav the decisive role on the stage of manipulation are the intermediaries: agents afl e-man ation or good-faith intermediaries. The agents of influence-manipulatio re the act receiving a role in the scenario of manipulation, which they perform. They a or ortance in the collectiveness the manipulation of which is aimed, they have renown audic Without having the overall vision of manipulation, without knowing the pr ject af manipu, a intervention, they have the consciousness of participation in an action influ e. In relation to the agents of influence-manipulation, the good-faith intermediaries agate a lessage about which they do not know what effects is seeks. They are dec rega $\mathrm{g}$ th goals and speeches which they automatically bring to stage. They are elf-su ested th what they say or do only has a momentary importance in the personal hish of the sta elying on the pride of notable people and on their will to stand out (Joule \& Beauvois, 1997).

A fey categories of people are taken as benchmarks, as influence-manipulation agents, as good faith intermediaries or as sounding boards in the actions of manipulation.

Above all, specialists seek journalists. They know that the objectivity of journalists is vulnerable, but is defended by that it is questioned only as an exception. On the other hand, more than in the case of any other professional category, journalist's word is not verified, it is felt. The law of Pascal-Kapferer acts primarily: "social knowledge is based on trust and not on evidence". The audience is sensitive to the press, especially for two reasons: it trusts the journalists and is almost always in a hurry. The audience does not think to verify, nor does it 
have the time to verify. Therefore, the journalist is the ideal actor for manipulation. What they manipulatively add to the basic information is perceived as what gets into their free will from the comment. The press information has a furious impact. The journalist is at the moment of rapid reading, as reading of seduction, beyond any suspicion. Beyond the law of PascalKapferer, once it is seduced, the audience's sensitivity to negative journalism is increased. It is no longer capable to observe the journalist's tendency towards self-importance, whom marks the manipulating information. It does no longer observe the relations of the journalism/journalist with the economical power or political power. Journalist's self-censorship or the censorship imposed by the managers of the funds or broadcast frequencies are 1 hard to detect.

Priests are social actors of great trust. They have a guaranteed and dedi ed audien That audience can be manipulated.

For their concern to do justice and for their power to do "a manipu ative justio vhe it comes to causes of social resonance, the magistrates have no longer he sus cion o seing propagators of persuasion. As such, they are seen as good faith inte vec s.

A persuasive force is also the business circles. In an eff to defe their rights" by actually promoting their great interests, these business circle $a$ into circl of interests, as they do not have any debts to conviction. The royal road pron ing the great interests is manipulation, often accompanied by constraints and vir

Scholars and teachers represent the ideal agents of manipulation to influentially intervene in the collectivities of youths and in the scientific o s. They have the vanity of professional success and do not hesitate to use means of pers ion. "The teacher is the seducer par excellence" shows Professor Constantin Cuans (Cucos -p. 91). Seduction is one of the fundamental operations of persuasion, an prevails along with the lie within manipulation. Therefore, professors are the pe fect litom alors: they enjoy trust and also have a seductive training. Their message $a$ n be eas $y$ modelled manipulatively, adding ideas to it on the project of the action of lant ation ( oiocaru, 2012). The stars in general, artists, writers are notabilities enjoyi ust. herefore, they can be credible and legitimate actors of a manipulative intervention 2005; Coman, 2011).

Being at the ce re tention, $t$ y are those whom have influence, and their influence can also have man husises. They are also trainers and guides of opinion. They are models. Therefo ie, they have th cisive qualities to be agents or good faith agents or sounding boards. A ca ory 9 dividuars may be very easily seduced: the young. Opinions, ideas and views triggerin. naviour can be grafted and are grafted manipulatively on its aspirations of origina on its dences to oppose the old, on the propensity to protest and contest, on the amb ion to ntroduc ew values. All these categorical vulnerabilities to persuasion are formed on a ck them moment of the tity crisis. Not having an identity fixed, the young seek it. In this search where the young in and wastes emotional and intellectual energies, seduction and fiction are easily articulated The vulnerability also represents factors favouring the manipulative intervention (Teodorescu, 2006; Peters, 2012).

The targets of manipulation must be integrated into a situation of manipulation wherein a manipulative message would be transmitted to them. Both the situation and the message are part of the project of organising and performing the action of manipulation.

The situation of manipulation is grafted on contacts between negotiators, demonstrations of military forces, economical pressures, press campaigns, etc. Manipulation valorises the ambiguities and indeterminacies. It is created in the areas of confused and debile knowledge, 
on the short interpersonal knowledge. It also raises on the interpersonal and inter-group tensions, exploiting the divergences and misunderstandings. The perimeter of manipulation extends to the border of the system of verification. As it is known, the law of Pascal-Kapferer says that, in general, "social knowledge is based on trust and not on evidence". As such, the manipulation can get very far (Panea, 2012; Panea, 2013). The situation of manipulation is a vitiated social situation. Manipulation starts from a political, economical, social, military, informational situation and changes it by means of manipulative messages. In manipulation, daily situations are distorted on the confused areas, so that they would acquire for the target the significations permeable to manipulation. Septimiu Chelcea (1994) considers that manimulation (of behaviour) consists in influencing the human subjects to perform actions ince asistent th their own purposes, without the latter becoming aware of the discrepancy bet en their o purposes and the distant purposes of those influencing them.

Manipulation exists, as we have interests which we would like to ar ineve throw oth is, without them knowing it. The manipulator and the manipulated are con cted b mant rative relation. Herein, the first one has a motif for the fulfilment of which he / find o timulate an opportunity, using the secondary as a means. The manipulate creates a anari, where the manipulated (an individual or a group) is destined to play a or at is unp ctable for the latter. In the script (scenario), that who has the control trodu their own interests for performance. They also install an eventful regime app opme to pre the access of the manipulated to the basic intentional substance of the approach. The minipulated one remains manipulated as long as they are under the power o foreign intention, seduced and lied to, incapable to think this intention does not belong to $t$. Seduct on, lie, myth, fabling are the functional elements of the manipulative pechanism. may also be added to them, unspecifically and narrowly: repetition, vio 1 ternation between tension and its absence (Tudor D., 2001, p. 77).

\section{CONCLUSION}

The manipulated $\mathrm{i}$ tool of ntention which does not belong to them in essence. The manipulative intentio is induced ntention. The manipulation is individualised by the deliberate intentio o produ changes of opinion, attitude, behaviour, turning to rational and emotional chniques unde conditions where the manipulated is outside the control concerning ty purps and meenanism of persuasive undertaking.

\section{ACKNOWLEDGMENT}

This w vas pupported by the grant number 33C/2014, awarded in the internal grant competition of the Universits Craiova.

\section{References}

[1] R. V. Joule, J. L. Beauvois (1997). Tratat de manipulare. Bucureşti, Editura Antet.

[2] Andrzej Borowski, International Letters of Social and Humanistic Sciences 14 (2014) 7-17. 
[3] Johnson A. J., Hample D., Cionea I. A. (2014). 5 Understanding Argumentation in Interpersonal Communication. Communication Yearbook 38.

[4] Sebastian Kot, Janusz Grabara, Michal Kolcun, International Letters of Social and Humanistic Sciences 15 (2014) 1-6.

[5] Veronica Ion (2012). The religiuos changes of the post communist Balkan societies. Revista de Stiinţe Politice.

[6] W. H. Riker (1986). The art of political manipulation (Vol. 587). Yale University Press.

[7] N. Lupaşcu (2012). Propaganda si manipulare, seductie sau convingere?.Log Universality, Mentality, Education, Novelty Section: Political Sciences and uropean Studies, (1), 103-119.

[8] B. Teodorescu (2007). Cinci milenii de manipulare. Ed. Tritonic.

[9] P. Bajdor, I. Grabara, Journal of Studies in Social Sciences 7(2)

[10] Gabriela Ilie Journal of Community Positive Practices 13(2, (2013)

[11] Andrzej Borowski, International Letters of Social and um. tic Scien es 14 (2014) $33-41$.

[12] M. Colhon (2013). Automatic Lexical Alignmen between Syntact ally Weak Related Languages. Application for English and Roma an. In Computational Collective Intelligence. Technologies and Applications ( $\mathrm{p}$ 66-275). pringer Berlin Heidelberg.

[13] D. Dunca (2013). Persuasiunea şi mâ larea-co uate etice şi pragmatice. Buletin Stiintific, seria A, Fascicula Filologie.

[15] Max G. Craig, Journal of Studies in Soci sciendes 8(1) (2014).

[16] J. D. Peters (2012). Speaki g int he Air: History of the Idea of Communication. University of Chicago

[17] Andrzej Borowski, nternation Vetters of Social and Humanistic Sciences 4 (2013) 70-74.

[18] G. Rajović, J L latov Internathonal Letters of Social and Humanistic Sciences 6 (2013) 24-2 s.

[19] Coman Gros (2012). Uncommonly Common or Truly Exceptional? An Alternati the Po ical System - Based Explanation of the Romanian Mass

The rng lonal Journal of Press/Politics, 1940161212450562.

[20 A. Bo Owski, Iv lernational Letters of Social and Humanistic Sciences 11 (2014) 1-168.

[21] tana Nicola Teodorescu (2006). Comunicarea, dificultăţile unei definiţii. Omagiu Ghe bolocan (pp. 527-537). Craiova: Editura Universitaria

[22] N. M. Sperdea, M. G. Mangra, M. Stanciu (2010). Trends Regarding The Level Of The Processing, Assortment Structure And The Quality Of The Food Products. Annals of the University of Petrosani, Economics.

[23] B. McNair (2011). An introduction to political communication. Taylor \& Francis.

[24] I. A. Coman (2011). US Mediated Public Diplomacy in a Crisis: Romanian Case Analysis of Romanian Media Versus US Embassy Framing. 
[25] Andrzej Borowski, International Letters of Social and Humanistic Sciences 2 (2014) $110-121$.

[26] M. Priku, J. Bushati, A. Sula, L. Kashahu, European Scientific Journal 10(14) (2014).

[27] S. Cojocaru, D. Cojocaru, O. Bunea (2010). Family strengthening program. Evaluation report (English version). Social Research Reports.

[28] O. M. Cuichi, A. Sandu (2010). Affirmative dimensions of applied ethics. Appreciative therapies. Revista de cercetare şi intervenţie social.

[29] A. Erich, E. Tîrziman (2007). Informaţie şi document în societatea cunoaşte Bibliotheca.

[30] S. Cojocaru (2012). Appreciative Approach in Social Work. Exceedin the Constructed by Deficiency Paradigm. Logos, Universality, Mental y, Educatio Novelty Section: Philosophy and Humanistic Sciences.

[31] D. Cojocaru (2012). Parenting education programs. What domain in Romania?. Logos, Universality, Mentality, E Philosophy and Humanistic Sciences.

[32] Ştefan Vlăduţescu, American International Journ woj Sontemp o Research 3(10) (2013).

[33] C. E. Ciovica, F. Cristian, V.-A. Enăchescu (2( ). Commu ication and conflict-an intercultural approach. Euromentor Journal-Stu about cducation.

[34] Vîlceanu, T. (2009). Cultural diversity ament and linguistic security. Analele Universităţii din Craiova. Seria Ştiinţe h lolosungistică.

[35] Băluţă O., Dragolea A., Iancy 2007). en şi interese politice. Teorii şi practici, (Gender and political inte ests. 1 eories a ypractices), Polirom, Iaşi.

[36] D. Rovenţa-Frumuşan 19, societate, cultură. Iaşi, Institutul.

[37] M. Coman (2005) dia anth Iogy: An overview. Media Anthropology Network Working Paper erio 7-24 Ma,. Available at: www. philbu. net/mediaanthropolos working rs. htm.

[38] Nicolae anea ( 012). Ant, Opologie Culturală Americană. Craiova: Editura Univesin

[39] (200 Utiv Zation of technology for linguistic processing in an electoral conte : Metho LIWC-2007. Proceedings of the Communication, Context, ter. Mondy Congress, Vol. 1, 87-98.

[40] Ja Grabara, Michal Kolcun, Sebastian Kot, International Journal of Education and Resed, ch 2(2) (2014).

[41] P. Anghel (2003). Stiluri şi metode de comunicare. Editura Aramis, Bucureşti.

[42] Nicolae Panea (2013). Orașul subtil. București: Editura Etnologică.

[43] Aurelia Traistaru (2013). Consolidation of the green marketing profile in current austerity period. Jokull.

[44] J. H. Gasderell, International Letters of Social and Humanistic Science 22 (2014) 85-91.

[45] F. Smarandache (1991). Only problems, not solutions!. Infinite Study. 
[46] M. Iovanescu, A. Radulescu (2000). La terminologie de la mode-entre l'emprunt au français et la création autochtone. Revue roumaine de linguistique.

[47] Cătălin Ghiță (2012). William Blake's aesthetic vision: Milton1. Memory, Identity and Intercultural Communication.

[48] Vlad Roşca Theoretical and Applied Economics 1(1) (2012) 127.

[49] Andrzej Borowski, International Letters of Social and Humanistic Sciences 3 (2013) 69-74.

[50] M. Spiridon (2004). Les dilemmes de l'identité aux confins de l'Europe: le l'Harmattan.

[51] Andrzej Borowski, International Letters of Social and Humanistic Scinces 2014) 100-110.

[52] Jason L. Powell, International Letters of Social and Humanisti ace $10(2,14)$ 177-183.

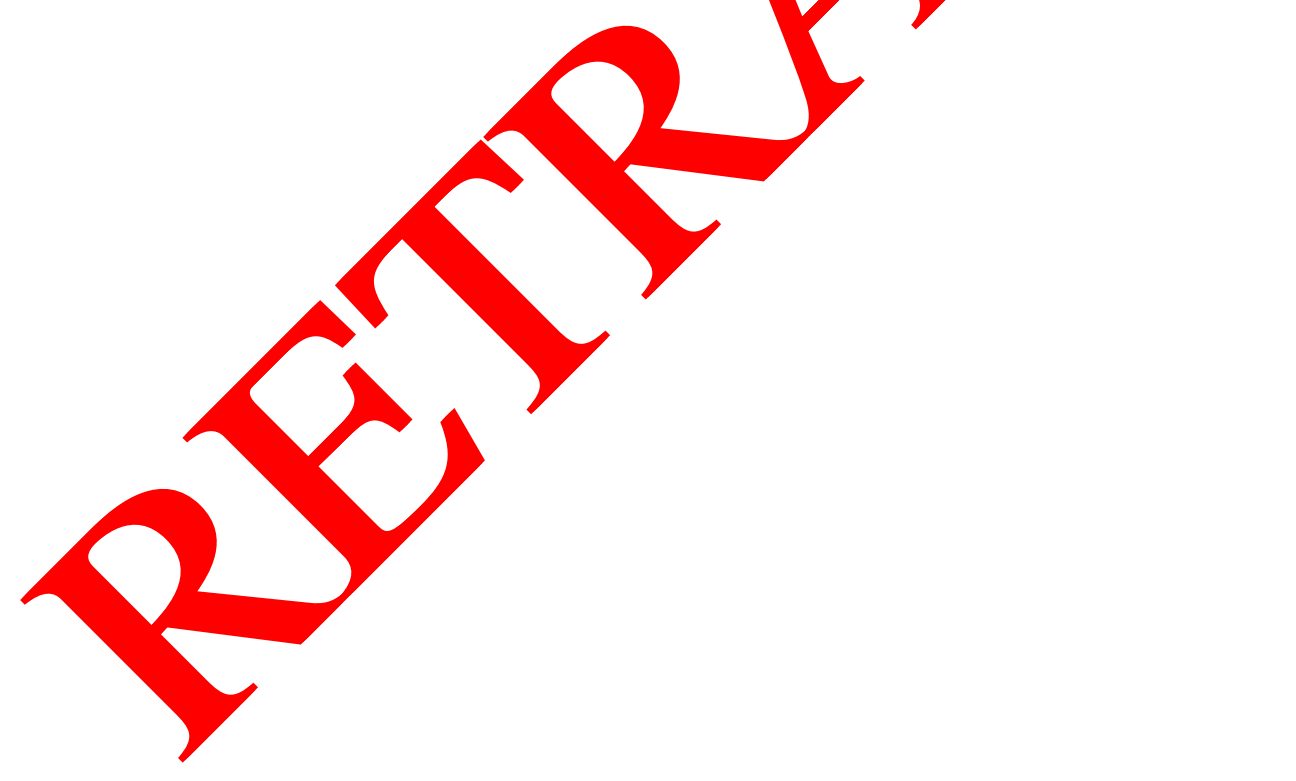

